University of Montana

ScholarWorks at University of Montana

Spring 2005

\title{
A Functional Analysis of American Vice Presidential Debates
}

William L. Benoit

Ohio University, Athens, OH, benoitw@ohio.edu

David Airne

University of Montana - Missoula, davidairne@gmail.com

Follow this and additional works at: https://scholarworks.umt.edu/communications_pubs

Part of the Communication Commons

Let us know how access to this document benefits you.

\section{Recommended Citation}

Benoit, William L. and Airne, David, "A Functional Analysis of American Vice Presidential Debates" (2005). Communication Studies Faculty Publications. 8.

https://scholarworks.umt.edu/communications_pubs/8

This Article is brought to you for free and open access by the Communication Studies at ScholarWorks at University of Montana. It has been accepted for inclusion in Communication Studies Faculty Publications by an authorized administrator of ScholarWorks at University of Montana. For more information, please contact

scholarworks@mso.umt.edu. 


\title{
A FUNCTIONAL ANALYSIS OF AMERICAN VICE PRESIDENTIAL DEBATES
}

\author{
William L. Benoit and David Airne
}

Compared to presidential debates, vice presidential debates tend to receive short shrift. Of course, there have been far fewer of them. No vice presidential debates were held in 1960 or 1980; other years featured two or three presidential debates but only one encounter between the vice presidential candidates. Through 2004, we have seen 7 debates from running mates but 23 debates featuring the top of the ticket. Unfortunately, scholars tend to ignore debates between the running mates of the presidential candidates. Numerous books (e.g., Benoit \& Wells, 1996; Benoit, McHale, Hansen, Pier, \& McGurie, 2003; Bishop, Meadow, \& Jackson-Beeck, 1978; Bitzer \& Rueter, 1980; Carlin \& McKinney, 1994; Coleman, 2000; Friedenberg, 1994, 1997; Hellweg, Pfau, \& Brydon, 1992; Hinck, 1993; Jamieson \& Birdsell, 1988; Kraus, 1962, 1977, 2000; Lanoue \& Schrott, 1991; Schroeder, 2000; Swerdlow, 1984, 1987) and many articles (e.g., Benoit, Hansen, \& Verser, 2003; Louden, 2005; Racine Group, 2002) have been published on presidential debates. In contrast, no books and a limited number of book chapters (e.g., Decker, 1994; Devlin, 1994; Ragsdale, 1997; Sauter, 1994; Trent, 1994) and articles (e.g., Beck, 1996; Carlin \& Bicak, 1993; Clayman, 1995; Sullivan, 1989) have investigated vice presidential debates.

Is this neglect reasonable? In 1963, Vice President Lyndon Johnson became presi-

William L. Benoit, Department of Communication, University of Missouri; David Airne, Department of Communication Studies, University of Alabama. William Benoit gratefully acknowledges the University of Missouri Research Council, which awarded him a Summer Research Fellowship to support this research. Correspondence concerning this article should be addressed to William $\mathrm{L}$. Benoit, Department of Communication, University of Missouri, Columbia, Missouri 65211-2310. E-mail: benoitw@missouri.edu dent after President John F. Kennedy was assassinated. However, voters had not had an opportunity to see Johnson, or Henry Cabot Lodge (Richard Nixon's running mate), in a vice presidential debate. In 2004, Gwen Ifill noted, "Ten men and women have been nominees of their parties since 1976 to be vice president." She then asked Senator Edwards, "What qualifies you to be a heartbeat away?" Obviously, election years in which vice presidential debates occur offer voters an extended opportunity to learn about, and compare, the vice presidential candidates. Furthermore, voters can learn about the presidential candidates because the vice presidential candidates also discuss their running mates. In fact, in 2004, Gwen Ifill felt compelled to demand that the candidates answer at least one question without mentioning their running mates; Edwards could not manage to do so.

Furthermore, it is clear that voters see value in vice presidential debates. Focus group participants in 1992 indicated that these encounters "served to highlight the presidential candidate's decision making and provided insight into the abilities of the vice presidential candidate" (Kay \& Borchers, 1994, p. 107). Tens of millions of viewers-an average of over 42 million-have watched the vice presidential debates. ${ }^{1}$ Research shows that watching vice presidential debates can influence opinions (Payne, Golden, Marlier, \& Ratzan, 1989; Wall, Golden, \& James, 1988), voters' perceptions of the candidates (Holbrook, 1994), and their voting intentions (Holbrook, 1994). Finally,

\footnotetext{
1 The average audience for a presidential debate in the same years was 49.7 million (Commission on Presidential Debates, 2005; see Table 1).
} 
TABLE 1.

Vice Presidential Debates, 1976, 1984-2004

\begin{tabular}{llllc}
\hline \hline & Date & \multicolumn{1}{c}{ Democrat } & Republican & Audience (millions) \\
\hline 1976 & $10 / 15$ & Walter Mondale & Bob Dole & 43.2 \\
1984 & $10 / 11$ & Geraldine Ferraro & George Bush & 56.7 \\
1988 & $10 / 5$ & Lloyd Bentsen & Dan Quayle & 46.9 \\
$1992 \dagger$ & $10 / 13$ & Al Gore & Dan Quayle & 51.2 \\
1996 & $10 / 9$ & Al Gore & Jack Kemp & 26.6 \\
2000 & $10 / 5$ & Joe Lieberman & Dick Cheney & 28.5 \\
2004 & $10 / 13$ & John Edwards & Dick Cheney & 43.5 \\
Total & - & - & - & 42.4 (mean) \\
\hline \hline
\end{tabular}

*Audience data from Commission on Presidential Debates: http:/www.debates.org/pages/history.html. †James Stockdale was the vice presidential candidate of the Reform Party in 1992.

as Carlin and Bicak (1993) explain, "Regardless of whether or not the [vice presidential] debates have a significant influence on an election's outcome, they serve an important educational function" (p. 120). Clearly, vice presidential debates merit scholarly attention.

In order to illuminate these important campaign events further, this study analyzes the seven American vice presidential debates held through 2004. Results are compared with content analysis of the presidential debates held in the same years (Benoit et al., 2005; Benoit, Blaney, \& Pier, 1998; Benoit \& Brazeal, 2002; Benoit \& Wells, 1996; Wells, 1999). First, the functional theory of political campaign discourse, which provides the underpinnings for this study, will be discussed. Then specific hypotheses will be advanced. The method will be explained. This will be followed by presentation of results and a discussion of the implications of the findings.

\section{Functional Theory of Polftical Campaign Discourse}

Carlin and Bicak (1993) identify five purposes of vice presidential debates: showing the nominees' fitness to serve as president, explaining their proposed role in administration, explaining policy positions, defending their running mate, and attacking the opponent. These purposes accord well with the three basic purposes of political campaign discourse identified in the functional theory. The first three are essentially acclaims (selfpraise) of the presidential and vice presidential candidates (who they are and what they will do if elected), the fourth is defense (response to attack), and the fifth is attack (criticism of an opponent).

Benoit (1999) argues that campaign discourse is functional, a means intended to accomplish an end. The end is to secure election to public office by obtaining the most votes from citizens. A candidate solicits support from voters by persuading them that he or she is preferable to opponents (according to whatever criteria are most important to each voter). Three functions in political campaign discourse can establish that one candidate is preferable to another. Acclaims, or self-praise, identify the advantages of a candidate. Attacks, or criticisms of an opponent, demonstrate the weaknesses of an opponent, thus increasing the attacking candidate's net desirability. Defenses, or responses to attacks, refute alleged weaknesses of a candidate. These three functions work together as an informal form of cost-benefit analysis: acclaims increase benefits, attacks increase an opponent's costs, and defenses reduce a candidate's alleged costs. The statement that this is an "informal" version of cost-benefit is meant to indicate that functional theory does not assume that all voters 
quantify costs and benefits or combine them mathematically. Instead, acclaims, when persuasive, tend to increase a candidate's perceived desirability. Attacks, when accepted by the audience, should tend to reduce an opponent's perceived desirability. Defenses, when effective, are likely to reduce a candidate's apparent costs.

Functional theory also posits that political campaign discourse occurs on only two kinds of topics: policy (issues such as taxes, jobs, terrorism, health care, Social Security, education) and character (e.g., honesty, compassion, courage, strength, leadership ability). Functional theory further subdivides both policy and character into three types. Policy includes past deeds, future plans, and general goals; character includes personal qualities, leadership ability, and ideals. The Appendix cites examples of acclaims and attacks on each form of policy and character taken from the 2004 vice presidential debate.

Research on presidential debates in 1960 and 1976-2004 has found that acclaims are more common than attacks $(57 \%$ to $35 \%)$ and that defense is the least common function (8\%; Benoit, 2005). The topics of presidential debates favor policy over character $(75 \%$ to $25 \%)$. Incumbent candidates acclaim more $(64 \%$ to $51 \%)$, attack less ( $25 \%$ to $44 \%$ ), and defend more $(12 \%$ to $6 \%)$ than challengers. Benoit (2004) reported that Democratic candidates in debates discuss policy more $(77 \%$ to $73 \%)$ and character less $(23 \%$ to 27\%) than Republicans. Benoit (2004) found that election winners discuss policy more than losers $(78 \%$ to $72 \%)$; losers address character more than winners $(28 \%$ to $22 \%)$. With this background in mind, we turn to the specific hypotheses and research questions addressed in this study.

The first prediction is specific to this message form. Carlin and Bicak (1993) argue that "a vice presidential nominee is not expected to be as 'presidential' as the presidential nominee. Thus, a more aggressive posture is expected" (p. 123). Consistent with this expectation, Walter Mondale observed in the first-ever vice presidential debate, in 1976 , that "Senator Dole has richly earned his reputation as a hatchet man tonight, by ... stating that World War II and the Korean War were Democratic wars." This means we should expect that vice presidential candidates will attack more than presidential candidates:

H1. Attacks will be more frequent in vice presidential debates than in presidential debates.

The remaining predictions are based on functional theory and past research on presidential debates. After we test a prediction with data from the vice presidential debates, we will compare these data with data from presidential debates. Functional theory anticipates that acclaims will be the most frequent function, followed by attacks and then defenses. Because acclaims have no drawbacks, candidates have no reason to moderate their use of this function. In contrast, many voters indicate that they do not like mudslinging, a reason for candidates to moderate their attacks, at least somewhat (Merritt, 1984; Stewart, 1975). Finally, defenses have three drawbacks. They make the candidate appear reactive rather than proactive. Given that one usually is attacked over one's weaknesses, defenses are likely to take a candidate off-message. Furthermore, one must identify an attack to refute it. This means that defending against an attack may remind or inform voters of an alleged weakness. For these reasons, we predict:

H2. Acclaims will be more common than attacks and defenses will be the least common function in vice presidential debates.

Functional theory contrasts incumbent party candidates with challenger party candidates. Among other differences, incumbent party candidates have a record in the office sought. Some challengers have records in other offices (e.g., the Senate or as a governor) but, arguably, experience in the 
White House is better evidence than experience elsewhere (e.g., no other office generates the kind of foreign policy experience that incumbent party candidates possess). Interestingly, the incumbent's record can be a source of acclaims (by the incumbent) and attacks (by the challenger) on past deeds. Therefore, we predict:

H3. Incumbent party candidates will acclaim more, and attack less, than challengers in vice presidential debates.

H4. Incumbent party candidates will acclaim more, and attack less, on past deeds than challengers in vice presidential debates.

Public opinion data indicate that policy matters more to voters in presidential elections than does character (Benoit, 2003). Past research on presidential primary and general election debates indicates that candidates stress policy more than character (Benoit et al., 2002). For this reason, we predict:

H5. Policy will be discussed more than character in vice presidential debates.

Research has indicated that Democrats tend to discuss policy more, and character less, than Republicans (Benoit, 2004). For this reason, we expect that:

H6. Democrats will discuss policy more, and character less, than Republicans in vice presidential debates.

Research also has found that winners tend to discuss policy more, and character less, than losers (Benoit, 2003). Thus, we predict:

H7. Winners will discuss policy more, and character less, than losers in vice presidential debates.

We posit two research questions concerning distribution of the forms of policy and character:

RQ1. What are the proportions of the three forms of policy in vice presidential debates?

RQ2. What are the proportions of the three forms of character in vice presidential debates?
Finally, we pose hypotheses regarding the use of general goals and ideals as the basis for acclaims and attacks. It is easier to praise a goal (such as more jobs, less inflation, greater security from terrorism) or an ideal (such as the right to education, opportunity, faith) than to attack them.

H8. General goals will be the basis of acclaims more often than attacks.

H9. Ideals will be the basis of acclaims more often than attacks.

Together, these hypotheses and research questions guide our analysis of American vice presidential debates.

\section{Method}

Transcripts of the seven American vice presidential debates were obtained from the Commission on Presidential Debates webpage (2005) and, for 1976, from Bitzer and Rueter (1980). Each debate was content analyzed for functions (acclaims, attacks, defenses), topics (policy, character), forms of policy (past deeds, future plans, general goals), and forms of character (personal qualities, leadership ability, ideals). Intercoder reliability was calculated on $10 \%$ of the texts using Cohen's (1960) $\kappa$, which corrects for agreement by chance. $\kappa$ for function was .95 , for topic was .96 , for forms of policy .98 , and for forms of character 1.0. Landis and Koch (1977) indicate that values of $\kappa$ of $0.81-1.00$ indicate "almost perfect" agreement among coders. This means that our data are sufficiently reliable for analysis.

Chi-square is used to analyze these data because it is the appropriate statistical test for differences using frequency (nominal, categorical) data. We report Cramer's $V$ as a measure of effect size (note that Cramer's $V$, as a measure of the size of the relationship between two variables, is not meaningful for one-way chi-squares because there is only one independent variable in a one-way chisquare). 
TABLE 2.

Functions of Vice Presidential Debates, 1976, 1984-2004

\begin{tabular}{|c|c|c|c|c|}
\hline & Acclaims & Attacks & Defenses & $\chi^{2}(d f=2)$ \\
\hline $\begin{array}{l}\text { Incumbent } \\
\text { Challenger }\end{array}$ & $\begin{array}{l}1346(62 \%) \\
1139(53 \%)\end{array}$ & $\begin{array}{l}748(35 \%) \\
984(45 \%)\end{array}$ & $\begin{array}{l}63(3 \%) \\
45(2 \%)\end{array}$ & $\begin{array}{c}52.37 \\
p<.0001, V=.11\end{array}$ \\
\hline $\begin{array}{l}\text { Democrats } \\
\text { Republicans }\end{array}$ & $\begin{array}{l}1274(59 \%) \\
1211(56 \%)\end{array}$ & $\begin{array}{l}847(39 \%) \\
885(41 \%)\end{array}$ & $\begin{array}{l}47(2 \%) \\
61(3 \%)\end{array}$ & $\begin{array}{l}4.22 \\
n s\end{array}$ \\
\hline $\begin{array}{l}\text { Total VP } \\
\text { Presidential } \\
1976,1984-2004\end{array}$ & $\begin{array}{l}2485\left(\begin{array}{l}57 \% \\
3607\end{array}(58 \%)\right.\end{array}$ & $\begin{array}{l}1732(40 \%) \\
2155(34 \%)\end{array}$ & $\begin{array}{l}108(2 \%) \\
498(8 \%)\end{array}$ & $\begin{array}{c}2047.78, p<.0001 \\
155.12^{*} \\
p<.0001, V=.13\end{array}$ \\
\hline
\end{tabular}

*This $\chi^{2}$ compares vice presidential and presidential debates.

Note: Presidential debate data from Benoit et al. (2005), Benoit, Blaney, \& Pier (1998), Benoit \& Brazeal (2002), Benoit \& Wells (1996), and Wells (1999).

\section{Results}

Our first prediction was that debates between vice presidential candidates would witness more attacks than presidential debates. Table 2 reports that $40 \%$ of themes in the vice presidential debates were attacks, compared with $34 \%$ of the themes in presidential debates (note that data from presidential debates only included years in which vice presidential debates also occurred, so that data from the 1960 and 1980 presidential debates were excluded). For example, Vice President Richard Cheney (2004) made this acclaim in the most recent vice presidential debate: "The world is far safer today because Saddam Hussein is in jail, his government is no longer in power." Obviously, a safer world is desirable. Senator John Edwards (2004), in contrast, attacked the BushCheney record in the same debate: "We lost more troops in September than we lost in August; lost more in August than we lost in July; lost more in July than we lost in June." The increasing numbers of American deaths would be a matter of concern for voters. After Edwards attacked Cheney over problems at Haliburton (where Cheney had been CEO), the vice president (Cheney, 2004) denied these accusations: "Well, the reason they keep mentioning Haliburton is because they're trying to throw up a smokescreen. They know the charges are false." The difference in function in vice presidential and presidential debates is significant with a moderate effect size $\left(\chi^{2}[d f=2]=155.12\right.$, $p<.0001, V=.13) .^{2}$

Hypothesis 2 predicted that acclaims would be more frequent than attacks and that defenses would be the least frequent function in vice presidential debates. This prediction was supported: Vice presidential debates witnessed $57 \%$ acclaims, $40 \%$ attacks, and $2 \%$ defenses. These differences were confirmed as significant with a one-way chi-square $\left(\chi^{2}[d f=2]=2047.29, p<.0001\right)$.

The next two hypotheses concern the potential effects of incumbency on functions of campaign messages. H3 predicted that incumbent party candidates would acclaim more and attack less than challengers. In these vice presidential debates, incumbents acclaimed $10 \%$ more than challengers $(63 \%$ to $53 \%)$ and attacked $11 \%$ less than challengers $(35 \%$ to $46 \%)$. These differences were

\footnotetext{
${ }^{2}$ Cramer's $V$ is a measure of effect size for categorical (frequency) data and is generally similar to Pearson's $r$. Both statistics can assume values between 0 (no relationship between variables) and 1 (a perfect relationship between variables), although unlike $r, V$ does not use negative values to indicate an inverse relationship. Beatty (2002) has argued that $r$ rather than $r^{2}$ is a better indication of effect size.
} 
TABLE 3.

Forms of Policy and Character in Vice Presidential Debates, 1976, 1984-2004

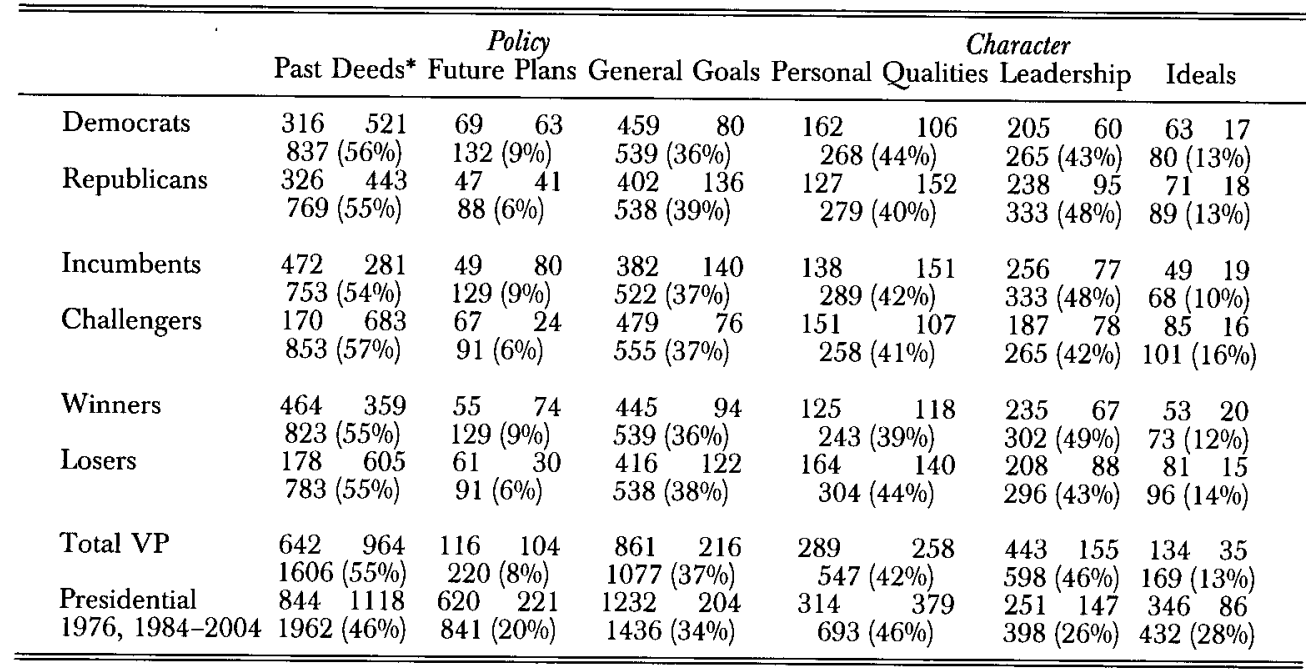

${ }^{*}$ Acclaims/attacks; percentages do not always total to $100 \%$ because of rounding.

Note: Presidential debate data from Benoit et al. (2005), Benoit, Blaney, \& Pier (1998), Benoit \& Brazeal (2002), Benoit \& Wells (1996), and Wells (1999).

significant $\left(\chi^{2}[d f=2]=52.37, p<.0001, V\right.$ $=.11)$, confirming this hypothesis.

The next prediction anticipated a difference in the use of past deeds: Incumbents would employ this form of policy more as acclaims, and less as attacks, than challengers. This hypothesis was confirmed. Incumbent party vice presidential candidates used past deeds to acclaim 472 times and to attack 281 times; in contrast, challengers used past deeds to acclaim 170 times and to attack 683 times. The above examples of an acclaim (by incumbent Cheney regarding making the world safer) and an attack (by challenger Edwards regarding deaths of American soldiers) show how an incumbent can acclaim and a challenger can attack on the basis of the incumbent administration's record. Statistical analysis confirms that these differences are significant with a relatively large effect size $\left(\chi^{2}[d f=1]=302.88, p<.0001\right.$, $V=.44$ ). See Table 3 for these data.

$\mathrm{H} 5$, concerning the topics of campaign messages, predicted that vice presidential debates would emphasize policy over char- acter. As hypothesized, $69 \%$ of utterances addressed policy while $31 \%$ addressed character $\left(\chi^{2}[d f=1]=598, p<.0001\right)$. For example, Edwards (2004) discussed policy when he brought up Cheney's record as a member of Congress:

When he was one of 435 members of the United States House, he was one of 10 to vote against Head Start, one of four to vote against banning plastic weapons that can pass through metal detectors. $\mathrm{He}$ voted against the Department of Education. He voted against funding for Meals on Wheels for seniors. He voted against a holiday for Martin Luther King. He voted against a resolution calling for the release of Nelson Mandela in South Africa.

In contrast, Cheney (2004) discussed character when revisiting charges that the Democrats had flip-flopped: "We have not seen the kind of consistency that a commander in chief has to have in order to be a leader in wartime and in order to be able to see the strategy through to victory." These data are displayed in Table 4.

H6 expected that Democrats would emphasize policy more, and character less, than 
TABLE 4.

Topics of Vice Presidential Debates, 1976, 1984-2004

\begin{tabular}{lccc}
\hline \hline & Policy & Character & $\chi^{2}(d f=1)$ \\
\hline Incumbent & $1404(67 \%)$ & $690(33 \%)$ & 6.06 \\
Challenger & $1499(53 \%)$ & $984(46 \%)$ & $p<.05, V=.04$ \\
Democrats & $1508(71 \%)$ & $613(29 \%)$ & 9.93 \\
Republicans & $1395(67 \%)$ & $701(33 \%)$ & $p<.005, V=.05$ \\
Winners & $1491(71 \%)$ & $618(29 \%)$ & 6.61 \\
Losers & $1412(67 \%)$ & $696(33 \%)$ & $p<.05, V=.04$ \\
Total VP & $2903(69 \%)$ & $1314(31 \%)$ & $598, p<.0001$ \\
Presidential 1976, 1984-2004 & $4239(74 \%)$ & $1523(26 \%)$ & $26.52^{*}$ \\
& & & $p<.0005, V=.05$ \\
\hline \hline
\end{tabular}

*This $\chi^{2}$ compares vice presidential and presidential debates.

Note: Presidential debate data from Benoit et al. (2005), Benoit, Blaney, \& Pier (1998), Benoit \& Brazeal (2002), Benoit \& Wells (1996), and Wells (1999).

Republicans. Candidates from both political parties focused more on policy than character, but Table 4 reports that Democrats discussed policy more $(71 \%$ to $67 \%)$ and character less (29\% to $33 \%$ ) than Republicans. These differences were statistically significant $\left(\chi^{2}[d f=1]=9.93, p<.005, V=.05\right)$ with a small effect size.

$\mathrm{H} 7$ predicted that winners would discuss policy more and character less than losers (note that we considered Gore/Lieberman the winner in 2000 because their campaign persuaded over half a million more voters; see Duchneskie \& Seplow, 2000). Once again, although candidates in both groups emphasized policy over character, still this prediction was supported. Winners discussed policy more frequently than losers $(71 \%$ to $67 \%)$; in contrast, losers stressed character more often than winners (33\% to $29 \%)$. These differences were statistically significant $\left(\chi^{2}[d f=1]=6.61, p<.05\right.$, $V=.04)$, but with a small effect size.

Table 3 also contains the answers to the two research questions. Vice presidential candidates most often discussed past deeds $(55 \%)$, followed by general goals $(37 \%)$ and, relatively infrequently, future plans $(8 \%)$. This distribution is significantly different from what would be expected by chance $\left(\chi^{2}\right.$ $[d f=2]=1011.12, p<.0001)$. When they addressed character, the vice presidential candidates mainly discussed leadership ability $(46 \%)$ and personal qualities $(42 \%)$, with fewer comments devoted to ideals (13\%). These frequencies were significantly different $\left(\chi^{2}[d f=2]=250.78, p<.0001\right)$.

The final two hypotheses concerned the frequency with which general goals and ideals were used as the basis for acclaims and attacks. In both cases, acclaims were almost four times as common as attacks. General goals formed the basis for 861 acclaims and 216 attacks, a significant difference $\left(\chi^{2}[d f=\right.$ 1] $=385.08, p<.0001)$. Similarly, ideals more frequently were employed to acclaim than attack (134 to 35 ), a distribution that was significantly different $\left(\chi^{2}[d f=1]=\right.$ $56.82, p<.0001)$.

\section{Discussion}

As Carlin and Bicak (1993) expected, vice presidential candidates are more "aggressive" than presidential candidates in debates, with $6 \%$ more attacks $(40 \%$ to $34 \%)$. These candidates are in a sense surrogates for their running mates and there is evidence that surrogates attack more than challengers. Benoit (2005) reported that convention keynote 
speeches attack more than nomination acceptance addresses and that party-sponsored advertisements attack more than candidatesponsored ads. In fact, it is a little surprising that the candidates in vice presidential debates did not attack even more frequently. However, unlike a keynote speaker, a vice presidential candidate can assume the presidency, which may constrain his or her willingness to "go negative."

Further, although Carlin and Bicak note that one of the five functions of vice presidential candidates in debate is to defend their running mates, defense actually was less common in vice presidential than in presidential debates ( $2 \%$ to $8 \%$ ). This is particularly noteworthy given that vice presidential candidates had more opportunities to defend than presidential candidates because there were more attacks in vice presidential than presidential debates $(40 \%$ to $34 \%)$. It appears that these campaigns wanted their vice presidential candidates to attack the opposition, and not so much defend against such attacks. Interestingly, Mondale (1976), who accused Dole of being a "hatchet-man" in the first vice presidential debate, attacked somewhat more frequently than Dole $(54 \%$ to $50 \%)$. It is possible that Mondale was referring to Dole's nasty tone rather than the frequency of his attacks, something which functional analysis does not attempt to quantify.

This study found that acclaims were the most frequent function of vice presidential debate utterances, followed by attacks and then defenses. This is consistent with findings on general election presidential debates (as noted in the literature review) and in presidential primary debates (Benoit et al., 2002). This distribution is reasonable because acclaims have no drawbacks, attacks risk provoking a backlash from voters who dislike mudslinging, and defenses have the three potential disadvantages noted above.

The vice presidential candidate of the incumbent party acclaimed more, and at- tacked less, than the challenger. This is consistent with past research on presidential debates (e.g., Benoit, 2005). The incumbent party candidate has a record in the office sought, arguably the best evidence of the candidate's future performance if returned to office. Although challengers have records as holders of other offices, governors, for example, have scant foreign policy experience and Senators have only legislative, not executive, experience. The incumbent party's record in the White House is arguably stronger evidence than the challenger's record in other arenas. Interestingly, the incumbent's record can be a resource for both candidates, but in different ways. Incumbents promote their record in office to acclaim their own successes, whereas challengers use the incumbent's record to attack the latter's failures. This means not only that incumbents acclaim more and attack less than challengers but that they do so particularly concerning past deeds (the incumbent's record in office).

As noted previously, according to public opinion data (Benoit, 2003), policy is more important than character in determining who voters prefer as president. It seems likely that vice presidential candidates are aware of this preference because, as is the case for presidential candidates (Benoit, 2005), vice presidential candidates debate policy more than character. Democrats emphasize policy even more (and character less) than Republicans. Benoit (2004) argues that Democrats are more likely to see governmental solutions to problems than $\mathrm{Re}$ publicans, which inclines Democrats to discuss policy more than their opponents.

Winning vice presidential candidates discussed policy more, and character less, than losers. This finding is consistent with research on presidential campaign messages, including general election debates (Benoit, 2003). Recall that more voters consider policy (not character) to be the most important determinant of their vote for president. This 
preference may advantage candidates who stress policy more than their opponents at the polls.

Nominees for the second spot on the ticket stress past deeds and general goals; they discuss future plans less frequently. In fact, vice presidential candidates discuss future plans less often than presidential candidates, $8 \%$ to $20 \%\left(\chi^{2}[d f=2]=207.63, p<\right.$ $.0001, V=.17$; recall that vice presidential candidates also discuss past deeds more than presidential candidates). It appears that a vice presidential candidate's task is to discuss the record and not to dwell on the details of his or her running mate's specific policy proposals.

Vice presidential candidates emphasized leadership ability and personal qualities more than ideals. Compared with presidential debates, vice presidential candidates discussed leadership ability more ( $46 \%$ to $26 \%$ ) and ideals less (13\% to $28 \%)$. These differences are significant $\left(\chi^{2}[d f=2]=250.78\right.$, $p<.0001)$. It is not surprising that these encounters, which are designed in part to assess whether a vice presidential candidate is qualified to be "a heartbeat away," emphasize leadership ability more than do presidential debates. With greater emphasis on past deeds than on ideals, perhaps they are meant to be more pragmatic as well.

Finally, as with presidential candidates (Benoit, 2005), vice presidential candidates tend to acclaim more and attack less regarding both general goals and ideals. Both kinds of utterances are easier to embrace than reject.

\section{Conclusion}

It is important for voters to learn about the vice presidential nominees, and debates provide an extended opportunity to do so. Of course, these candidates also talk about their running mates in the debates, providing information about both members of the ticket. Unfortunately, the scholarly literature has devalued vice presidential debates even though these debates have attracted an average of 42 million viewers (compared with 50 million presidential debate viewers). Several studies have found that watching these events has important effects (Holbrook, 1994; Payne, Golden, Marlier, \& Ratzan, 1989; Wall, Golden, \& James, 1988). This study has advanced our understanding of the nature of vice presidential campaign debates.

We now know that vice presidential debates resemble presidential debates in many respects. Both are primarily positive; both defend infrequently. Both emphasize policy more than character. Incumbent party candidates in both acclaim more than challengers, who in turn attack more than incumbents. The record of the incumbent party is particularly salient, and candidates in both presidential and vice presidential debates use this record differently: Incumbents acclaim more, and attack less, than challengers on the basis of past deeds. Democrats and winning candidates discuss policy more, and character less, than Republicans and losing candidates. Candidates in both kinds of debates tend to use general goals and ideals more to acclaim than to attack. The many important similarities between presidential and vice presidential debates suggest that the constraints of the situation strongly influence the discourse of these important campaign events.

On the other hand, there are some differences as well. Candidates in both kinds of debates acclaimed at virtually the same rate $(57 \%$ in vice presidential, $58 \%$ in presidential), but vice presidential debaters devote about four in ten statements to attacks, which is higher than presidential debaters $(34 \%)$, but not as much higher as might be expected. Oddly, vice presidential candidates defend much less than presidential candidates $(2 \%$ to $8 \%)$, despite the fact that vice presidential candidates had more opportunities to defend than presidential candidates. 
Candidates for the second spot on the ticket also are less likely to discuss specific policy proposals than the nominees at the top of the ticket $(8 \%$ in vice presidential debates, $20 \%$ in presidential debates). Vice presidential debates discuss character more than presidential debates. In particular, vice presidential candidates stress leadership ability much more than do presidential candidates $(46 \%$ to $26 \%$ ), which is not surprising given that one of the purposes of these debates is to demonstrate the vice presidential candidates' fitness for office. So, the fact that vice presidents are not as prominent as presidents results in some important differences.

The 2008 presidential campaign promises to be interesting. Vice President Cheney has indicated that he does not plan to run for president at the end of his second term. If he does not change his mind, 2008 will witness the first truly open presidential campaign, i.e., in which neither candidate is the sitting president or vice president, since Eisenhower faced Stephenson in 1952. It will be important to examine the nature of the vice presidential debate in such an unusual campaign. Our understanding of vice presidential debates also should be advanced by further research employing diverse other approaches, such as metaphor (Henry, 1988), language (Hart, 2000), and civic dialogue (Kaid, McKinney, \& Tedesco, 2000).

\section{REFERENCES}

Beatty, M. J. (2002). Do we know a vector from a scalar? Why measures of association (not their squares) are appropriate indices of effect. Human Communication Research, 28, 605-611.

Beck, C. S. (1996). "I've got some points I'd like to make here": The achievement of social face through turn management during the 1992 vice presidential debate. Political Communication, 13, 165-180.

Benoit, W. L. (1999). Seeing spots: A functional analysis of presidential television advertisements from 1952-1996. New York: Praeger.

Benoit, W. L. (2003). Presidential campaign discourse as a causal factor in election outcome. Western Journal of Communication, 67, 97-112.

Benoit, W. L. (2004). Political party affiliation and presidential campaign discourse. Communication Quarterly, $52,81-97$.
Benoit, W. L. (2005). Political campaign communication: $A$ functional approach. Manuscript submitted for publication.

Benoit, W. L., Blaney, J. R., \& Pier, P. M. (1998). Campaign '96: A functional analysis of acclaiming, attacking, and defending. New York: Praeger.

Benoit, W. L., \& Brazeal, L. M. (2002). A functional analysis of the 1988 Bush-Dukakis presidential debates. Argumentation and Advocacy, 38, 219-233.

Benoit, W. L., Hansen, G. J., \& Verser, R. M. (2003). A meta-analysis of the effects of viewing U.S. presidential debates. Communication Monographs, 70, 335-350.

Benoit, W. L., McHale, J. P, Hansen, G. J., Pier, P. M., \& McGuire, J. P. (2003). Campaign 2000: A functional analysis of presidential campaign discourse. Lanham, MD: Rowman \& Littlefield.

Benoit, W. L., Pier, P. M., Brazeal, L. M., McHale, J. P., Klyukovksi, A., \& Airne, D. (2002). The primary decision: A functional analysis of debates in presidential primaries. Westport, CT: Praeger.

Benoit, W. L., Stein, K. A., McHale, J. P., Chattopadhyay, S., Verser, R., Price, S. (2005). Bush versus Kerry: A functional analysis of campaign 2004. Unpublished manuscript.

Benoit, W. L., \& Wells, W. T. (1996). Candidates in conflict: Persuasive attack and defense in the 1992 presidential debates. Tuscaloosa: University of Alabama Press.

Bitzer, L., \& Rueter, T. (1980). Carter vs. Ford: The counterfeit debates of 1976. Madison: University of Wisconsin Press.

Bishop, G. F., Meadow, R. G., \& Jackson-Beeck, M. (Eds.). (1978). The presidential debates: Media, electoral, and policy perspectives. New York: Praeger.

Carlin, D. B., \& Bicak, P. J. (1993). Toward a theory of vice presidential debate purposes: An analysis of the 1992 vice presidential debate. Argumentation and Advocacy, 27, 119-130.

Carlin, D. P., \& McKinney, M. S. (Eds.). (1994). The 1992 presidential debates in focus. Westport, CT: Praeger.

Cheney, R. (2004). The Cheney-Edwards Vice Presidential debate. Accessed September 2, 2005, from: http:// www.debates.org/pages/trans2004b.html

Clayman, S. E. (1995). Defining moments, presidential debates, and the dynamics of quotability. Journal of Communication, 45, 118-146.

Cohen, J. (1960). A coefficient of agreement for nominal scales. Educational and Psychological Measurement, 20, 37-46.

Coleman, S. (2000). Televised election debates: International perspectives. New York: St. Martin's.

Commission on Presidential Debates. (2005). Debate history. Accessed September 1, 2005, from: http:// www.debates.org/pages/history.html

Decker, W. D. (1994). The 1988 Quayle-Bentsen vice presidential debate. In R. V. Friedenberg (Ed.), Rhetorical studies of national political debates, $1960-1992\left(2^{\text {nd }}\right.$ ed., pp. 162-185). Westport, CT: Praeger.

Devlin, L. P. (1994). The 1992 Gore-Quayle-Stockdale vice presidential debate. In R. V. Friedenberg (Ed.), Rhetorical studies of national political debates, 1960-7992 ( $2^{\text {nd }}$ ed., pp. 211-233). Westport, CT: Praeger.

Duchneskie, J., \& Seplow, S. (2000, December 15). Gore's vote lead totals 540,435. Philadelphia Inquirer, p. Al.

Edwards, J. (2004). The Cheney-Edwards Vice Presidential debate. Accessed September 2, 2005, from: http:// www.debates.org/pages/trans2004b.html

Friedenberg, R. V. (Ed.). (1994). Rhetorical studies of national political debates, $1960-1992\left(2^{\text {nd }}\right.$ ed.). Westport, CT: Praeger. 
Friedenberg, R. V. (Ed.). (1997). Rhetorical studies of national political debates-1996. Westport, CT: Praeger.

Hart, R. P. (2000). Campaign talk: Why elections are good for us. Princeton, NJ: Princeton University Press.

Hellweg, S. A., Pfau, M., \& Brydon, S. R. (1992). Televised presidential debates: Advocacy in contemporary America. New York: Praeger.

Henry, D. (1988). The rhetorical dynamics of Mario Cuomo's 1984 keynote address: Situation, speaker, metaphor. Southern Speech Communication Journal, 53, 105-120.

Hinck, E. A. (1993). Enacting the presidency: Political argument, presidential debates, and presidential character. Westport, CT: Praeger.

Holbrook, T. M. (1994). The behavioral consequences of vice-presidential debates: Does the undercard have any punch? American Politics Quarterly, 22, 469-482.

Ifill, G. (2004, October 5). The Cheney-Edwards Vice Presidential debate. Accessed September 2, 2005, from: http://www.debates.org/pages/trans2004b.html

Jamieson, K. H., \& Birdsell, D. S. (1988). Presidential debates: The challenge of creating an informed electorate. New York: Oxford University Press.

Kaid, L. L., McKinney, M., \& Tedesco, J. C. (2000). Civic dialogue in the 7996 presidential campaign: Candidate, media, and public voices. Cresskill, NJ: Hampton Press.

Kay, J., \& Borchers, T. A. (1994). "Children in a sandbox": Reaction to the vice presidential debate. In D. B. Carlin \& M. S. McKinney (Eds.), The 1992 presidential debates in focus (pp. 99-108). New York: Praeger.

Kraus, S. (Ed.). (1962). The great debates. Bloomington: Indiana University Press.

Kraus, S. (Ed.). (1977). The great debates: Carter versus Ford, 1976. Bloomington: Indiana University Press.

Kraus, S. (2000). Televised presidential debates and public policy ( $2^{\text {nd }}$ ed.). Mahwah, NJ: Erlbaum.

Landis, J. R., \& Koch, G. G. (1977). The measurement of observer agreement for categorical data. Biometrics, 33, 159-174.

Lanoue, D. J., \& Schrott, P. R. (1991). The joint press conference: The history, impact, and prospects of American presidential debates. Westport, CT: Praeger.

Louden, A. (2005). Political debates: Selected bibliography. Accessed February 24, 2005, from: http://www.wfu. edu/\%7Elouden/Political $\% 20$ Communication/Bibs/ DEBATES.html

Merritt, S. (1984). Negative political advertising: Some empirical findings. Journal of Advertising, 13, 27-38.

Mondale, W. (1976). Vice Presidential debate. Accessed September 2, 2005, from: http://www.debates.org/ pages/his_1976.html

Payne, J. G., Golden, J. L., Marlier, J., \& Ratzan, S. C. (1989). Perceptions of the 1988 presidential and vicepresidential debates. American Behavioral Scientist, 32, 425-435.

Racine Group. (2002). White paper on televised political campaign debates. Argumentation and Advocacy, 38, $199-218$.

Ragsdale, G. (1997). The 1996 Gore-Kemp vice presidential debate. In R. V. Friedenberg (Ed.), Rhetorical studies of national political debates-1996 (pp. 31-60). Westport, CT: Praeger.

Sauter, K. (1994). The 1984 Mondale-Dole vice presidential debate. In R. V. Friedenberg (Ed.), Rhetorical studies of national political debates, $1960-1992\left(2^{\text {nd }} \mathrm{ed}\right.$., pp. 45-68). Westport, CT: Praeger.

Schroeder, A. (2000). Presidential debates: Forty years of high-risk TV. New York: Columbia University Press.
Stewart, C. J. (1975). Voter perception of mud-slinging in political communication. Central States Speech Journal, 26, $279-286$.

Sullivan, P. A. (1989). The 1984 vice-presidential debate: A case study of female and male framing in political campaigns. Communication Quarterly, 37, 329-343.

Swerdlow, J. L. (1984). Beyond debate: A paper on televised presidential debates. New York: Twentieth Century Fund.

Swerdlow, J. L. (Ed.). (1987). Presidential debates 1988 and beyond. Washington, DC: Congressional Quarterly Inc.

Trent, J. S. (1994). The 1988 Bush-Ferraro vice presidential debate. In R. V. Friedenberg (Ed.), Rhetorical studies of national political debates, 1960-1992 (2 $2^{\text {nd }} \mathrm{ed}$., pp. 121-144). Westport, CT: Praeger.

Wall, V., Golden, J. L., \& James, H. (1988). Perceptions of the 1984 presidential debates and a select 1988 presidential primary debate. Presidential Studies Quarterly, 18, 541-563.

Wells, W. T. (1999). An analysis of attacking, acclaiming, and defending strategies in the 1976-1984 presidential debates. (Doctoral Dissertation, University of Missouri, Columbia, 1999). Dissertation Abstracts International, 61,2106 .

\section{APPENDIX}

Sample acclaims and attacks on forms of policy and character are taken from the 2004 Cheney-Edwards vice presidential debate in Cleveland, Ohio (Cheney, 2004; Edwards, 2004).

\section{Pourcy}

\section{Past Deeds}

Acclaim (Cheney): "We've captured or killed thousands of $\mathrm{Al}$ Qaida in various places around the world and especially in Afghanistan ... We've got 10 million voters who have registered to vote [in Afghanistan], nearly half of them women... They have done wonders writing their own constitution for the first time ever. Schools are open. Young girls are going to school. Women are going to vote. Women are even eligible to run for office. This is major, major progress."

Attack (Edwards): "In the time that they have been in office, in the last four years, 1.6 million private sector jobs have been lost, 2.7 million manufacturing jobs have been lost. And it's had real consequences in places like Cleveland. Cleveland ... has the highest poverty rate in the country. One out of almost two 
children in Cleveland are now living in poverty. During the time that the vice president and the president have been in office, 4 million more Americans have fallen into poverty. And what the most striking and startling thing is, they are the first presidency in 70 years-and I'm talking Democrats, Republican, presidents who led us through World War, through the Korean War, the Vietnam War, Cold Warevery one of them created jobs until this president."

\section{Future Plans}

Acclaim (Edwards): "We need [to] speed up the training of the Iraqis, get more staff in for doing that. We need to speed up the reconstruction so the Iraqis see some tangible benefit."

Attack (Edwards): "They also didn't have a plan to win the peace."

\section{General Goals}

Acclaim (Edwards): "We want to get rid of tax cuts for companies sending jobs overseas. We want to balance this budget, get back to fiscal responsibility. And we want to invest in the creative, innovative jobs of the future."

Attack (Edwards): "This vice president has been an advocate for over a decade for lifting sanctions against Iran, the largest state sponsor of terrorism on the planet. It's a mistake."

\section{Character}

\section{Personal Qualities}

Acclaim (Cheney): "I come from relatively modest circumstances. My grandfather never even went to high school. I'm the first in my family to graduate from college. I carried a ticket in the International Brother- hood of Electrical Workers for six years. I've been laid off, been hospitalized without health insurance. So I have some idea of the problems that people encounter."

Attack (Edwards): "And you've gone around the country suggesting that there is some connection [between Saddam Hussein and the attacks of 9/11]. There is not. And in fact the CIA is now about to report that the connection between Al Qaida and Saddam Hussein is tenuous at best. And, in fact, the secretary of defense said yesterday that he knows of no hard evidence of the connection. We need to be straight with the American people."

\section{Leadership Ability}

Acclaim (Cheney): "Well, I clearly believe that George W. Bush would be a better commander in chief. He's already done it for four years. And he's demonstrated, without question, the conviction, the vision, the determination to win this war against terror."

Attack (Cheney): "I'm saying specifically that I don't believe [Kerry] has the qualities we need in a commander in chief because I don't think, based on his record, that he would pursue the kind of aggressive policies that need to be pursued if we're going to defeat these terrorists."

\section{Ideals}

Acclaim (Cheney): "I believe today that freedom does mean freedom for everybody. People ought to be free to choose any arrangement they want [including same-sex relationships]."

Attack (Cheney): "I think the Kerry-Edwards approach basically is to ... give government more control over the lives of individual citizens." 
Copyright of Argumentation \& Advocacy is the property of American Forensic Association. The copyright in an individual article may be maintained by the author in certain cases. Content may not be copied or emailed to multiple sites or posted to a listserv without the copyright holder's express written permission. However, users may print, download, or email articles for individual use. 